\title{
Interrelations of calcium, fluorine and vitamin D in bone metabolism
}

\author{
By DEBORAH GASTER, E. HAVIVI AND K. GUGGENHEIM \\ Department of Nutrition, Hebrew University-Hadassah \\ Medical School, ferusalem, Israel
}

(Received 6 October I966-Accepted I9 December I966)

\begin{abstract}
I. The interrelationships between dietary calcium, fluorine and vitamin $\mathrm{D}$ were studied in young rats.

2. Rats maintained on a low-Ca diet gained less weight and had less ash in their bones. Their femurs incorporated more radioactive $\mathrm{Ca}$ than those of rats kept on a control diet. Supplementation of the diet with F slightly decreased growth and the content of bone ash without any effect on the content of $\mathrm{Ca}$ and phosphorus in the bone ash. The $\mathrm{F}$ supplement decreased uptake of radioactive $\mathrm{Ca}$ by bone. Addition of vitamin $\mathrm{D}$ to a low- $\mathrm{Ca}$ diet improved growth and, when added alone, increased uptake of radioactive $\mathrm{Ca}$ by bone without affecting the content in femurs of ash, Ca or P. Addition of F to a low-Ca diet supplemented with vitamin D diminished the uptake of radioactive $\mathrm{Ca}$.

3. Decrease of bone ash in rats fed the low-Ca diet was accompanied by an increase in bone nitrogen. The bones of the unsupplemented rats contained less citric acid per unit of dry, fat-free mass. Addition of $F$ decreased citric acid, whereas addition of vitamin $D$ increased it. 4. The results are discussed and it is concluded that vitamin $\mathrm{D}$ added to a low-Ca diet does not exert a calcifying effect on bone, but rather increases $\mathrm{Ca}$ turnover. $\mathrm{F}$, on the other hand, reduces the exchangeability of bone mineral.
\end{abstract}

Vitamin D increases the intestinal absorption of calcium. This effect is more evident in animals subsisting on a low-Ca diet than when the diet supplies sufficient amounts of $\mathrm{Ca}$ (Dowdle, Schachter \& Schenker, 1960). The increased intestinal absorption of $\mathrm{Ca}$ is believed to be one of the main reasons for the calcifying effect of vitamin D on bone (Dam \& Søndergaard, I964). A direct action of vitamin D on bone cannot, however, be excluded. Such effects have been described in rachitic rats and children by Greenberg (I945), Lindquist (I95I), Carlsson (I952) and Bauer, Carlsson \& Lindquist (1956) and in surviving bones in vitro (Au \& Bartter, I966).

Dietary fluorine is deposited in the skeleton by means of incorporation into the bone salt molecule or by heteroionic exchange (Underwood, ig62). The crystallinity of bone improves with an increase of $\mathrm{F}$ content of the diet or water (Menczel, Posner, Schraer, Pakis \& Likins, I962). Furthermore, the Ca balance of osteoporotic patients can be improved by administration of $\mathrm{F}$ (Rich \& Ensinck, I96r). Thus, it is possible that dietary $\mathrm{F}$ affects bone resorption.

The purpose of the study was to compare the effects of vitamin $D$ and $F$ and their interrelations in bone metabolism in the rat. It was reasoned that the effects would be more pronounced if the investigation were carried out in animals maintained on a low-Ca diet. 


\section{METHODS}

Male rats of a local strain, 3-4 weeks old and weighing $35-40 \mathrm{~g}$, were used throughout. They were kept in individual cages with raised screen bottoms.

The control diet was composed of $(\mathrm{g} / \mathrm{I} 00 \mathrm{~g})$ : casein $\mathrm{I} 8$, maize starch 73 , vegetable oil 5 and salt mixture (no. 2 US Pharmacopeia, XIII, I947) 4. To each kg of this diet the following vitamins were added: 1000 i.u. vitamin $\mathrm{A}, 0.6 \mathrm{mg}$ thiamine, $0.6 \mathrm{mg}$ riboflavine, $0.2 \mathrm{mg}$ pyridoxine, $x^{\circ} 0 \mathrm{mg}$ calcium pantothenate, $4^{\circ} \mathrm{mg}$ nicotinamide and $100 \mathrm{mg}$ choline chloride. This diet contained $4.34 \mathrm{~g} \mathrm{Ca}$ and $0.5 \mathrm{r} \mathrm{mg} \mathrm{F}$ per $\mathrm{kg}$. The low-Ca diet had a similar composition. Only the salt mixture was different and consisted of $(\mathrm{g} / \mathrm{I} 00 \mathrm{~g})$ ferrous sulphate 6.0 , magnesium sulphate $24^{\circ} \circ$, sodium chloride $8 \cdot 0$, dibasic potassium phosphate $44^{\circ} 0$ and monobasic sodium phosphate $18 \cdot 0$. This diet contained $\mathrm{I} \cdot 2 \mathrm{~g} \mathrm{Ca}$ and also $0.5 \mathrm{I} \mathrm{mg} \mathrm{F}$ per $\mathrm{kg}$. The low-Ca diet was offered either unsupplemented or supplemented with $50 \mathrm{mg}$ fluorine (as $\mathrm{NaF}$ ) per $\mathrm{kg}$ or with vitamin $\mathrm{D}$ or with both supplements. Rats supplemented with vitamin $\mathrm{D}$ received 200 i.u./I00 g body-weight three times weekly. Liquid 'Ostelin' (Glaxo Research Ltd, Greenford Mddx.), containing 5000 i.u. calciferol $/ \mathrm{ml}$ in arachis oil, was used; it was diluted with soya oil to $400 \mathrm{i} . \mathrm{u}$./ml before administration. The drinking water supplied was distilled and contained less than ro $\mu \mathrm{g} \mathrm{F} / \mathrm{l}$. There were, therefore, five experimental groups, each comprising nine or ten rats.

After 4 weeks, ${ }^{45} \mathrm{Ca}$ was administered as a solution of $\mathrm{CaCl}_{2}$ containing $32 \mu \mathrm{g}$ carrier $\mathrm{Ca} / \mathrm{ml}$. Each rat received by stomach tube or subcutaneous injection approximately 600000 counts/min per Io g body-weight. On the next day the animals were killed and their femurs and tibias thoroughly cleaned and weighed. One femur and tibia were broken, extracted for $3 \mathrm{~h}$ in ethanol and for $3 \mathrm{~h}$ in diethyl ether in a Soxhlet apparatus, dried and used for determination of nitrogen and citric acid. The other femur and tibia were ashed for $8 \mathrm{~h}$ at $55^{\circ}$ for determination of $\mathrm{Ca}$ and phosphorus. A measured portion of this ash was dissolved in $\mathrm{I} \mathrm{N}-\mathrm{HCl}$, and radioactivity was determined in a Packard Liquid Scintillation Counter with toluene $(6 \mathrm{ml}$ per counting vial) and absolute ethanol ( $4 \mathrm{ml}$ per counting vial) as solvents. 2,5-Diphenyloxazole ( $5 \mathrm{~g} / \mathrm{l}$. toluene) and I,4-bis-2-(5-phenyloxazolyl) benzene (100 $\mathrm{mg} / \mathrm{l}$. toluene) were used as primary and secondary fluors; $0.1 \mathrm{ml}$ of the acidic solution of bone ash was added to each counting vial. The results are expressed as percentage of dose per $100 \mathrm{mg}$ ash.

$\mathrm{N}$ in bone was determined by the well-known Nessler method, after wet-ashing with concentrated $\mathrm{H}_{2} \mathrm{SO}_{4}$, and a selenium catalyst. Citric acid was determined by the method of Taylor (1953), Ca in ash by that of Baron \& Bell (1959) and P by that of Fiske \& Subbarow (1925). F was determined in the ash of the diet according to Hall (I963).

\section{RESULTS}

\section{Effect of $C a, F$ and vitamin $D$ on weight increase and bone minerals (Table I)}

The weight gain of the rats fed on a low-Ca diet was approximately one-half that of the rats on the control diet $(P<0.01)$. Vitamin D supplementation significantly 
Vol. 2I

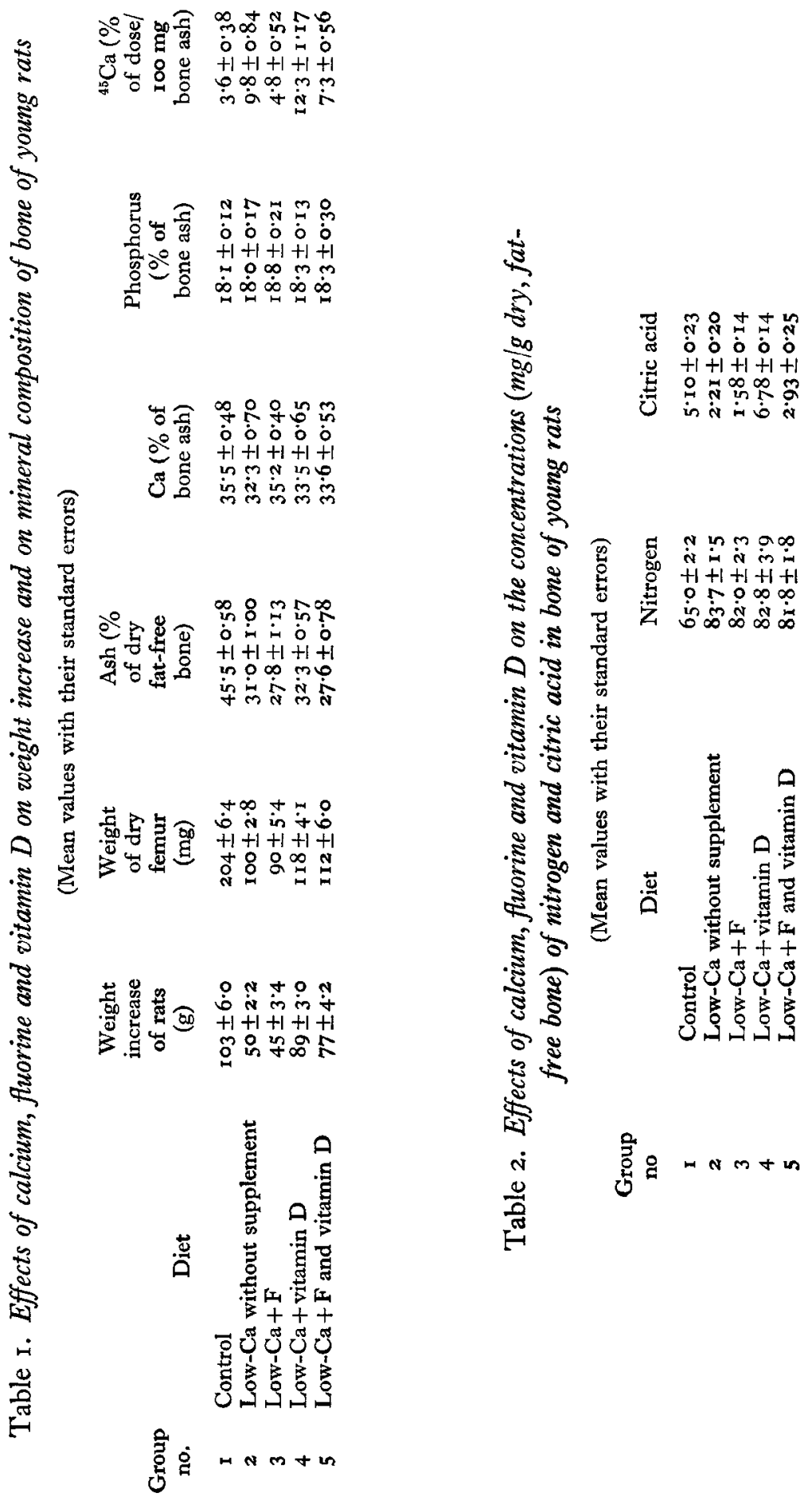


increased the weight gain to levels only slightly less than that of the controls $(P<0.01)$. This large increase in body-weight, effected by vitamin $\mathrm{D}$, contrasts with the very small differences in femur weight. This contrast may be clearly seen in the ratio of body-weight gain to femur weight, which was consistently 500 in all rats not receiving additional vitamin $\mathrm{D}$ and close to 700 in groups 4 and 5 which received it.

Fluorine supplementation resulted in a small decrease in both body-weight $\left(P<O^{\prime} I\right)$ and femur weight $\left(P<O^{\circ} \mathrm{I}\right)$.

The ash content of the bones of rats fed on the low-Ca diet was significantly lower than that of the controls. Neither vitamin D nor F increased the ash content of bone. All experimental groups were similar to the control group with respect to concentration of $\mathrm{Ca}$ and $\mathrm{P}$ in ash.

Bone of rats maintained on the unsupplemented low-Ca diet incorporated (on peroral administration of ${ }^{45} \mathrm{Ca}$ ) much more radioactive $\mathrm{Ca}$ than bone of the control rats $(P<0.0 \mathrm{I})$. Supplementation with vitamin $\mathrm{D}$ alone increased the uptake of radioactive $\mathrm{Ca}$ over that seen in bone of rats fed on the unsupplemented low-Ca diet. In an additional similar experiment, in which ${ }^{45} \mathrm{Ca}$ was administered by subcutaneous injection, vitamin $\mathrm{D}$ was again observed to increase the incorporation of radioactive $\mathrm{Ca}$ by bone. When ${ }^{45} \mathrm{Ca}$ was given subcutaneously, $5 \cdot 44 \pm 0 \cdot 79 \%$ of the dose was incorporated into $100 \mathrm{mg}$ bone ash in rats fed on the low-Ca diet compared with $7.22 \pm 0.12 \%$ in rats fed on the same diet and receiving additional vitamin D $(P<0.05)$. Thus, it appears that the effect of vitamin D on the uptake of radioactive $\mathrm{Ca}$ by bone is not solely the result of improved intestinal absorption of $\mathrm{Ca}$.

Addition of $\mathrm{F}$, alone or in combination with vitamin $\mathrm{D}$, to the low-Ca diet resulted in a markedly diminished uptake of ${ }^{45} \mathrm{Ca}$ by bone $(P<0.01)$.

\section{Effect of $\mathrm{Ca}, \mathrm{F}$ and vitamin $\mathrm{D}$ on concentrations of nitrogen and citric acid of bone (Table 2)}

Lack of dietary $\mathrm{Ca}$ greatly increased the concentration of $\mathrm{N}$ in dry, fat-free bone. This increase in $\mathrm{N}$ paralleled the decrease in bone ash in rats fed on the low-Ca diets regardless of supplementation with $\mathrm{F}$, vitamin $\mathrm{D}$ or both. The ratio of bone ash to bone $\mathrm{N}$ was 7.0 in the control group and between 3.4 and 3.9 in the low-Ca groups.

An unsupplemented low-Ca diet also led to decreased concentration of citric acid in bone $(P<0.01)$. Addition of $\mathrm{F}$ to the low-Ca diet significantly decreased bone citric acid $(P=0.02)$, whereas addition of vitamin $D$ resulted in substantially increased citric acid in bone.

\section{DISCUSSION}

Our experiments show that the bones of growing rats maintained on a diet low in $\mathrm{Ca}$ had characteristically lower ash contents and higher $\mathrm{N}$ contents than bones of normal controls. The bones of these rats also incorporated more radioactive $\mathrm{Ca}$ than those of control rats. Rarefaction of bones and impaired mineralization have frequently been found when a low-Ca diet is given, particularly in young animals which are more susceptible to the effects of low $\mathrm{Ca}$ intakes (Moore, Impey, Martin \& Symonds, 1963$)$. 
Increased uptake of strontium or radioactive $\mathrm{Ca}$ by bone in $\mathrm{Ca}$-deficient animals has been found by Carlsson (195I), Harrison \& Fraser (1960a) and Menczel, Schraer, Pakis, Posner \& Likins ( $\left.{ }^{96} 6_{3}\right)$ and has been interpreted by Harrison \& Fraser ( $1960 a$ ) as a sign of increased bone avidity for Ca. Harrison $\&$ Fraser (1960 $b$ ) demonstrated that a Ca-deficient diet increases parathyroid activity leading to impaired calcification. The significance of an increased uptake of radioactive $\mathrm{Ca}$ by bone has been discussed by Bronner (1964), who suggests that it may express an increase in the exchangeability of the bone mineral.

Supplementation of the low-Ca diet with vitamin D resulted in a greatly increased gain in body-weight; this gain was disproportionate to the gain in bone weight. Such a generalized stimulation of growth by vitamin $\mathrm{D}$ has long been known (Bicknell \& Prescott, 1946). Addition of vitamin D to the low-Ca diet had no effect on bone ash, nor did it affect the ratio of ash to organic material, which is a sensitive index of bone mineralization. Vitamin $\mathrm{D}$ also increased the uptake of ${ }^{45} \mathrm{Ca}$ by bones of rats maintained on a low-Ca diet. These results are in agreement with those of Hartles, Leaver \& Triffitt ( 1964 ), who have shown that, when rats are fed on diets low in $\mathrm{Ca}$, the presence of vitamin $\mathrm{D}$ produces a porotic bone. All these bone changes affected by vitamin $\mathrm{D}$ would support the idea that at minimal levels of $\mathrm{Ca}$ intake addition of vitamin $\mathrm{D}$ results in an increase in the rate of bone resorption rather than a calcifying effect. Campbell \& Douglas ( 1965 ) have claimed that the effect of vitamin D in circumstances of $\mathrm{Ca}$ deficiency is to prevent, or reduce, a fall in the level of plasma $\mathrm{Ca}$ by increasing the rate of bone resorption. In studies with human subjects Bell \& Bartter (1963) observed increased rates of $\mathrm{Ca}$ turnover following treatment with vitamin $\mathrm{D}$, and Nichols, Schartum \& Vaes (1963) showed increased mobilization of Ca from bones of mice treated with vitamin $\mathrm{D}$.

The close relationship between vitamin $\mathrm{D}$ and the citrate content of bone was clearly demonstrated in our experiments. The results agree with the views of Hartles, Leaver \& Triffitt (1963) that the accumulation of citrate in bone is directly governed by vitamin $\mathrm{D}$ when the diet is low in $\mathrm{Ca}$. Our results also support their findings that in the absence of added vitamin $\mathrm{D}$, a sufficiency of dietary $\mathrm{Ca}$ maintains a nearly normal concentration of bone citrate.

Supplementation of the diet with F, on the other hand, resulted in a marked decrease in the level of bone citrate. The exact significance of a decreased citrate content of bone is not known; an increased content, however, is thought to make bone salt more easily soluble and therefore potentially more mobile (Dixon \& Perkins, 1956). It may be assumed that decreased bone citrate is associated with lower solubility. Zipkin, Posner \& Eanes ( 1962 ), as the result of X-ray diffraction studies, reported that $\mathrm{F}$ decreased the effective surface per unit mass of bone, thus reducing the reactivity of bone apatite. Less citrate was, therefore, deposited as the concentration of $F$ administered increased (Zipkin, Schraer, Schraer \& Lee, I963). These findings conform with those of Menczel et al. ( $\mathrm{r}^{6} 6_{3}$ ) that bone crystallinity is improved by adding $\mathrm{F}$ to the drinking water, regardless of the $\mathrm{Ca}$ content of the diet.

In a similarly striking fashion, $\mathrm{F}$ was seen to decrease the uptake of ${ }^{45} \mathrm{Ca}$ by bone while even slightly reducing its content of ash. These findings are in agreement with 
those of Menczel et al. (I963) who kept rats on a normal or a low-Ca diet with or without the addition of $\mathrm{F}$ to the drinking water. After $\mathrm{I} 4$ months radioactive $\mathrm{Ca}$ was administered. Addition of $\mathrm{F}$ to the low-Ca diet was found to have decreased the incorporation of radioactive $\mathrm{Ca}$ into bone, but to have had no effect in the rats maintained on the control diet.

The skilled technical assistance of Miss A. Dayan is gratefully acknowledged.

The study was supported by a grant from the Authority for Research and Development of the Hebrew University, Jerusalem, Israel.

\section{REFERENCES}

Au, W. Y. W. \& Bartter, F. C. (1966). Endocrinology 78, 1100.

Bauer, G. C. H., Carlsson, A. \& Lindquist, B. (1956). Metabolism 5, 573.

Baron, D. N. \& Bell, J. L. (1959). F. clin. Path. 12, I43.

Bell, N. H. \& Bartter, F. C. (1963). Trans. Ass. Am. Physns 76, I63.

Bicknell, F. \& Prescott, F. (1946). The Vitamins in Medicine, and ed., p. 645. London: William Heinemann Medical Books Ltd.

Bronner, F. (1964). In Mineral Metabolism. Vol. 2, p. 303. [C. L. Comar and F. Bronner, editors.] London and New York: Academic Press Inc.

Campbell, J. R. \& Douglas, T. A. (I965). Br. F. Nutr. 19, 339.

Carlsson, A. (195I). Acta pharmacol., Kbh. 7, Suppl. I.

Carlsson, A. (1952). Acta physiol. scand. 26, 212.

Dam, H. \& Søndergaard, E. (1964). In Nutrition, a Comprehensive Treatise. Vol. 2, p. 20. [G. H. Beaton and E. W. McHenry, editors.] London and New York: Academic Press Inc.

Dixon T. F. \& Perkins, H. R. (1956). In The Biochemistry and Physiology of Bone, p. 581. [G. H. Bourne, editor.] London and New York: Academic Press Inc.

Dowdle, E. B., Schachter, D. \& Schenker, H. (1960). Am. J. Physiol. 198, 269.

Fiske, C. H. \& Subbarow, Y. (1925). F. biol. Chem. 66, 375 .

Greenberg, D. M. (1945). F. biol. Chem. 157, 99.

Hall, R. J. (1963). Analyst, Lond. 88, 76 .

Harrison, M. \& Fraser, R. (I960a). F. Endocr. 21, 197.

Harrison, M. \& Fraser, R. (1960b). F. Endocr. 21, 207.

Hartles, R. L., Leaver, A. G. \& Triffitt, J. T. (I963). Archs oral Biol. 8, 657.

Hartles, R. L., Leaver, A. G. \& Triffitt, J. T. (1 964). Archs oral Biol. 9, 725.

Lindquist, B. (I95I). Acta paediat., Stockh. 40, Suppl. 83, p. 87.

Menczel J., Posner, A. S., Schraer, H., Pakis, G. \& Likins, R. C. (r962). Proc. Soc. exp. Biol. Med. rro, 609.

Menczel, J., Schraer, R., Pakis, G., Posner, A. S. \& Likins, R. C. (1963). Proc. Soc. exp. Biol. Med. IIz, 128.

Moore, T., Impey, S. G., Martin, P. E. N. \& Symonds, K. R. (r963). F. Nutr. 8o, 162.

Nichols, H. Jr, Schartum, S. \& Vaes, G. M. (I963). Acta physiol. scand. 57, 5 I.

Rich, C. \& Ensinck, J. (I96r). Nature, Lond. I9r, I84.

Taylor, T. G. (1953). Biochem. $\%$. 54, 48.

Underwood, E. J. (1962). Trace Elements in Human and Animal Nutrition, 2nd ed., p. 259. London and New York: Academic Press Inc.

US Pharmacopeia, XIII (1947), p. 72x.

Zipkin, I., Posner, A. S. \& Eanes, E. D. (1962). Biochim. biophys. Acta 59, 255.

Zipkin, I., Schraer, R., Schraer, H. \& Lee, W. A. (1963). Archs oral Biol. 8, 19. 